\title{
Reaction of Peach Genotypes to Bacterial Leaf Spot: Correlations with Environmental Conditions, Leaf Phenology, and Morphology
}

\author{
Marcos R. Sachet ${ }^{1,6}$, Idemir Citadin ${ }^{2}$, Silvia Scariotto ${ }^{1}$, \\ Idalmir dos Santos ${ }^{3}$, and Pedro H. Zydek ${ }^{4}$ \\ Technological Federal University of Paraná, Cx. P. 571, 855503-390, Pato \\ Branco, PR, Brazil
}

\author{
Maria do Carmo B. Raseira ${ }^{5}$ \\ Embrapa Temperate climate, Cx. P. 403, 96010-971, Pelotas, RS, Brazil
}

Additional index words. Prunus persica, Xanthomonas, disease resistance, stability

\begin{abstract}
In breeding programs, it is essential to understand how characteristics are expressed by the germplasm in relation to the selection environment. The reactions of 15 peach genotypes to bacterial leaf spot (BLS) during three growing seasons (2008-09, 2009-10, and 2010-11) were investigated. Quantitative assessments were made from three plants per genotype through a modified healthy leaf area duration (HAD) method. None of the genotypes were immune to the disease. The most resistant were 'Cascata 1055', 'Conserva 985', 'Cascata 967', and 'Cascata 1065'. There was a reduction in HAD with increased precipitation. The leaf dry matter (g/leaf), leaf blade length, leaf length (with petiole), and leaf area ( $\left.\mathrm{cm}^{2} / \mathrm{leaf}\right)$ were inversely correlated with genotype resistance to BLS. The HADs of susceptible genotypes were influenced by the number of wet days regardless of temperature. The most susceptible genotypes were those with earlier budburst and fruit ripening. A shorter duration of healthy leaf area was related to earlier budburst and flowering in the subsequent year. We found no relationship between HAD and productivity.
\end{abstract}

The worldwide area dedicated to peach cultivation is expanding. In 2010, the crop covered an area of $1,537,400$ ha with an average yield of $13,190 \mathrm{~kg} \cdot \mathrm{ha}^{-1}$ (FAOSTATStatistical Database of the Food and Agriculture Organization of the United Nations, 2012). In Brazil, the production of 220,739 tons of fruit is still not sufficient to meet domestic market demand, and $\approx 21,500$ tons of fresh fruit (peaches and nectarines) and 9,000 tons of processed fruit were imported in 2010. Exportation of fresh fruits was practically nil and only 930 tons of canned fruits were exported (IBRAF-Instituto Brasileiro de Frutas, 2012).

The expansion of peach culture to humid subtropical regions has been possible as a result of selection and release of low-chill cultivars. BLS caused by Xanthomonas arboricola pv. pruni (Smith, 1903) Vauterin et al., 1995, is an increasing problem for peach growers in

Received for publication 22 Aug. 2012. Accepted for publication 1 Nov. 2012.

This research was supported in part by the Embrapa Clima Temperado, CNPq (Conselho Nacional de Desenvolvimento Científico e Tecnológico) and Fundação Araucária.

${ }^{1}$ Graduate Student.

${ }^{2}$ Adviser and Horticulture Professor.

${ }^{3}$ Phytopathologist Professor.

${ }^{4}$ Undergraduate Student.

${ }^{5}$ Fruit Breeder.

${ }^{6}$ To whom reprint requests should be addressed; e-mailidemir@utfpr.edu.br. warmer subtropical regions, and preventive techniques should be emphasized because chemical control is generally ineffective.

According to Battilani et al. (1999), primary infections of BLS are always established after at least three consecutive rainy days with temperatures between 14 and $19^{\circ} \mathrm{C}$. Disease progression is correlated with the number of rainy days during a growing season, and precipitation accounts for more than $90 \%$ of the variability in the incidence and severity of infection represented in a logistic regression model.

The reliable detection of peach germplasm resistant to BLS with potential use in subtropical climates is strategically important. Resistant genotypes would reduce production costs, enabling increased cultivation in subtropical areas. Resistance to BLS is considered to be a horizontal-type resistance and moderately heritable, and it should be possible to incorporate it into new peach selections (Topp et al., 1993).

The aim of the present research was to classify peach genotypes based on their susceptibility to BLS and to examine the correlation between bacterial reaction and morphological features of leaves, phenology, productivity, and climate.

\section{Materials and Methods}

The study area consisted of a collection of peach trees located at the experimental area of the Technological Federal University of Paraná [Universidade Tecnológica Federal do Paraná (UTFPR)] in the Pato Branco, Paraná State (altitude $764 \mathrm{~m}$, lat. $26^{\circ} 10^{\prime} \mathrm{S}$, long. $52^{\circ} 41^{\prime} \mathrm{W}$ ). The soil in this region is typically distroferric red latosols with a clay texture and alic properties in a subtropical evergreen forest phase with undulated topography (Bhering et al., 2008). The site is located in an area of humid subtropical climate (Cfa Köeppen classification). Trees were grown in $4 \mathrm{~m} \times 5-\mathrm{m}$ spacing and pruned twice a year (winter and summer). Disease control consisted of lime sulfur applications during winter followed by applications of azoxystrobin and tebuconazole during the growing season to control the leaf rust caused by Tranzschelia discolor (Fuckel). None of the fungicides used control BLS disease.

Fifteen genotypes, all of which originated from the Embrapa Temperate Climate (Pelotas, RS, Brazil) breeding program (Fig. 1), were evaluated during the 2008-09, 2009-10, and 2010-11 growing seasons. All genotypes required less than $\approx 650$ chilling hours and were considered to have intermediate or low-chilling requirements (Table 1). The experimental design was a completely randomized block with three replications (trees) and five shoots per tree (plots) tagged at random by the end of the dormant season. Five monthly evaluations were made on each shoot, beginning on 15 Nov. and ending on 15 Mar. of each growing season. Fully expanded leaves on each of five shoots per tree were individually rated to provide a disease estimate for each shoot.

The incidence, severity, and defoliation caused by the bacterial infection were quantified at each evaluation. The diagrammatic scale developed by Citadin et al. (2008) was used to assess severity (Fig. 2). The scale presents six levels of disease severity $(0.5 \%$, $1.5 \%, 4.3 \%, 12.0 \%, 29.1 \%$, and $55.3 \%$ ) with $0.5 \%$ the lowest severity perceptible in a leaf and $55.3 \%$ the highest severity found. Above this value, leaf abscission occurs. For composition of diagrammatic scale, it was considered the maximum and minimum proportion of leaf-damaged area found in field conditions and estimated in area integrator (LI-COR 3100 ), as being the maximum and minimum values of the diagrammatic scale. The other intermediate levels have been defined mathematically by a logarithmic scale according to the Weber-Fechner law of human acuity (Horsfall and Barrat, 1945). The scale provided goods levels of accuracy and precision of visual estimates, was considered adequate to estimate bacterial disease severity in peach, and can be used in epidemiological studies.

A comparison among genotypes was performed using a modification of the duration of healthy leaf area model (Waggoner and Berger, 1987) to express the values in each shoot with a maximum severity of $55.3 \%$ (Citadin et al., 2008; Medeiros et al., 2011).

$H A D=\sum_{i=1}^{n} \frac{\left[\left(F_{i}-S_{i} / 55.3\right) / F_{0}+\left(F_{i+1}-S_{i+1} / 55.3\right) / F_{0}\right]}{2} *\left(t_{i+1}-t_{i}\right)$ 


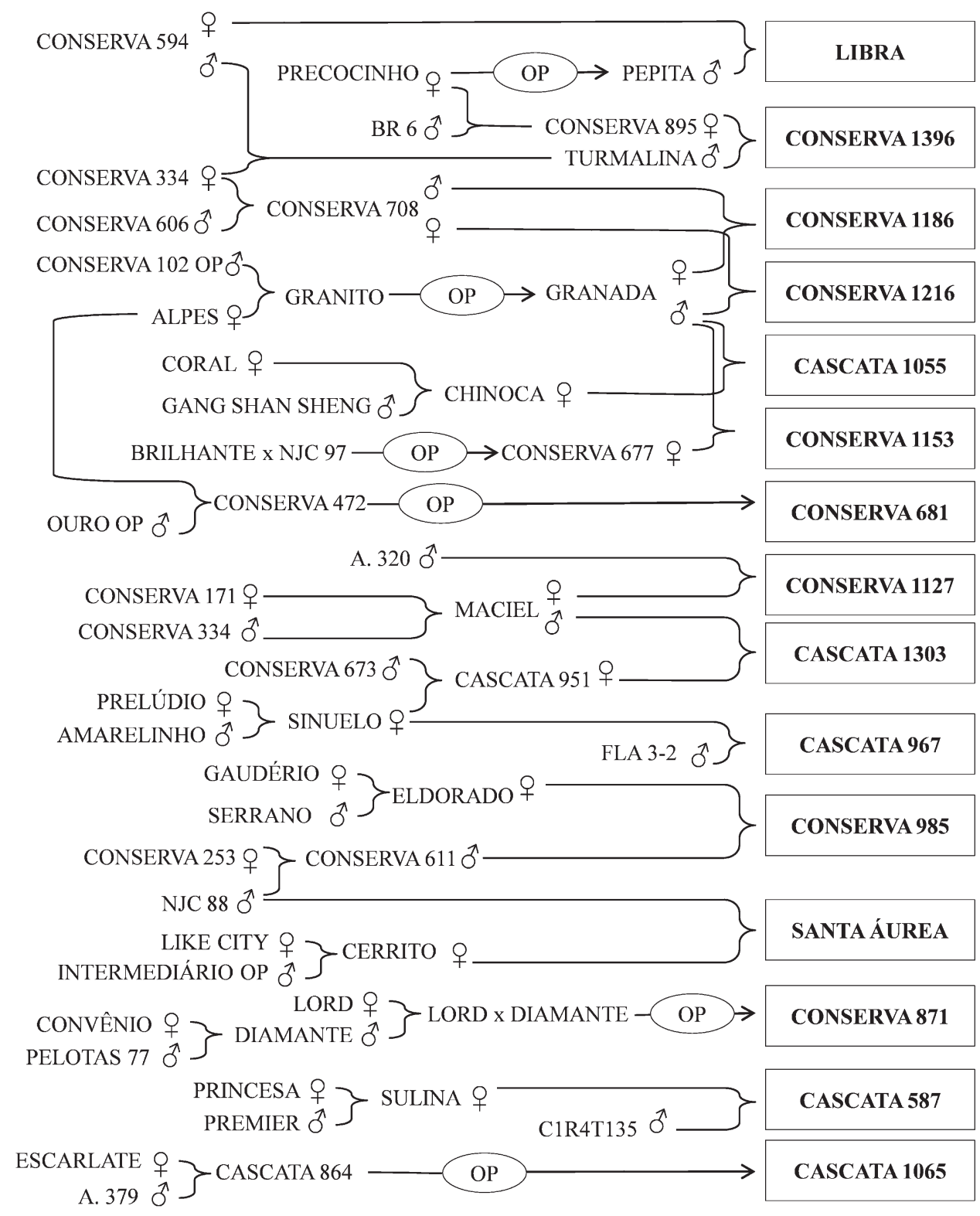

Fig. 1. Genealogy of 15 genotypes from Embrapa Temperate Climate Breeding Program (Pelotas, RS, Brazil). OP = open pollenization.

where $\mathrm{HAD}=$ healthy leaf area duration; $\mathrm{n}=$ number of evaluations; $\mathrm{Fi}=$ number of leaves on the shoots at evaluation $i$; $S i=$ sum of the severity $(\%)$ from the leaves of each shoot at the time of evaluation $i ; 55.3=$ maximum severity possible in the leaf, before defoliation $(\%) ; \mathrm{F}_{0}=$ number of leaves on the shoots in the first observation; and $\left(t_{i+1}-t_{i}\right)=$ the time interval between two consecutive evaluations. The first part of the equation $\left[\left(\mathrm{F}_{\mathrm{i}}-\mathrm{S}_{\mathrm{i}}\right)\right.$ $55.3) / \mathrm{F}_{0}$ ] expresses the healthy leaf area index (HLAI) at evaluation $\mathrm{i}$.

The maximum leaf blade width and length and the petiole length were measured in fully expanded leaves in the intermediate portion of the shoot. The measurement of the leaf area was made using an area integrator (LI-COR 3100). The leaves were then weighed on a precision scale, wrapped in paper bags, and placed in an incubator at $60{ }^{\circ} \mathrm{C}$ for $7 \mathrm{~d}$. After drying, the samples were reweighed. The means of the following parameters were calculated: fresh weight $\left(\mathrm{g} / \mathrm{leaf}\right.$ and $\left.\mathrm{g} \cdot \mathrm{cm}^{-2}\right)$; dry matter $\left(\mathrm{g} /\right.$ leaf and $\left.\mathrm{g} \cdot \mathrm{cm}^{-2}\right)$; dry matter content $(\%)$; blade length $(\mathrm{cm})$; petiole length $(\mathrm{cm})$; length of the leaf with petiole $(\mathrm{cm})$; blade width $(\mathrm{cm})$; leaf area $\left(\mathrm{cm}^{2} / \mathrm{leaf}\right)$; and leaf shape (length/width).

The stomates were counted by making an imprint of the leaf blade using a colorless nail polish resin. The resin formed a film that retained the shape of the stomata, which were counted at $400 \times$ magnification using a light microscope. The leaf samples consisted of five leaves from each of three trees of each genotype. The leaves were collected from the center of each shoot and the stomates counted from the tip, middle, and base of each leaf. Images were captured of four microscopic fields per area using a digital camera attached to the microscope, yielding a total of 2700 fields in this experiment.

The following data were obtained from the work of Scariotto (2011): date of budburst and flower initiation, the number of chilling hours below $12{ }^{\circ} \mathrm{C}$ accumulated from May until beginning of leaf budburst, date of full maturity, and yield (kg/plant).

Ambient temperature and humidity measurements on date of assessment were used to group evaluation days into four classes. 1) dry/mild: relative humidity $(\mathrm{RH}) 70 \%$ or less and daily mean temperature (DMT) $20{ }^{\circ} \mathrm{C}$ or less; 2) dry/hot: RH 70\% or less and DMT greater than $20^{\circ} \mathrm{C} ; 3$ ) humid/mild: $\mathrm{RH}$ greater than $70 \%$ and DMT $20{ }^{\circ} \mathrm{C}$ or less; and 4) humid/hot: RH greater than $70 \%$ and DMT greater than $20^{\circ} \mathrm{C}$.

The normality of HAD values was tested using the Shapiro-Wilk test, and homoscedasticity was evaluated using Bartlett's test. Analysis of variance was calculated on HAD, and means were compared using ScottKnott's test $(P \leq 0.05)$. Adaptability and stability analysis was performed using the GGE Biplot method (Yan and Kang, 2003) 
Table 1. The average number (2007-10) of hours of temperature below $12{ }^{\circ} \mathrm{C}(\mathrm{CH})$ accumulated until beginning of budburst $(5 \%)$ and healthy leaf area duration (HAD) for 15 peach genotypes in three growing seasons (2008 to 2011).

\begin{tabular}{|c|c|c|c|c|c|c|}
\hline \multirow[b]{2}{*}{ Genotypes } & \multirow{2}{*}{$\begin{array}{c}\mathrm{CH} \text { means of } \\
2007-10\end{array}$} & \multicolumn{3}{|c|}{ HAD (days) } & \multirow[b]{2}{*}{ Mean } & \multirow[b]{2}{*}{ Group $^{y}$} \\
\hline & & 2008 & 2009 & 2010 & & \\
\hline Conserva 1216 & 265 & $107.4 \mathrm{Ad}^{\mathrm{z}}$ & $97.3 \mathrm{Bd}$ & $97.7 \mathrm{Bd}$ & 100.8 & Susceptible \\
\hline Conserva 1396 & 304 & $114.9 \mathrm{Ac}$ & $94.4 \mathrm{Bd}$ & $92.9 \mathrm{Bd}$ & 100.7 & $102 \mathrm{~d}$ \\
\hline Conserva 1153 & 291 & $116.8 \mathrm{Ac}$ & $92.3 \mathrm{Bd}$ & $90.5 \mathrm{Bd}$ & 99.8 & \\
\hline Libra & 238 & $100.6 \mathrm{Ae}$ & $103.9 \mathrm{Ac}$ & $102.9 \mathrm{Ac}$ & 102.5 & \\
\hline Conserva 1127 & 311 & $124.4 \mathrm{Ab}$ & $105.6 \mathrm{Bc}$ & $97.1 \mathrm{Cd}$ & 109.0 & \\
\hline Conserva 681 & 521 & $134.8 \mathrm{Aa}$ & $121.4 \mathrm{Bb}$ & $108.4 \mathrm{Cc}$ & 121.5 & Moderately resistant \\
\hline Conserva 871 & 568 & $134.9 \mathrm{Aa}$ & $127.5 \mathrm{Bb}$ & $105.6 \mathrm{Cc}$ & 122.7 & $124 \mathrm{~d}$ \\
\hline Cascata 587 & 652 & $135.5 \mathrm{Aa}$ & $127.1 \mathrm{Bb}$ & $108.1 \mathrm{Cc}$ & 123.6 & \\
\hline Santa Áurea & 581 & $136.4 \mathrm{Aa}$ & $124.4 \mathrm{Bb}$ & $116.2 \mathrm{Cb}$ & 125.7 & \\
\hline Conserva 1186 & 421 & $136.8 \mathrm{Aa}$ & $130.6 \mathrm{Aa}$ & $106.4 \mathrm{Bc}$ & 124.6 & \\
\hline Cascata 1303 & 369 & $135.1 \mathrm{Aa}$ & $122.4 \mathrm{Bb}$ & $121.1 \mathrm{Bb}$ & 126.2 & \\
\hline Cascata 1055 & 596 & $140.7 \mathrm{Aa}$ & $128.1 \mathrm{Bb}$ & $126.1 \mathrm{Ba}$ & 131.6 & Resistant \\
\hline Conserva 985 & 353 & $135.5 \mathrm{Aa}$ & $131.3 \mathrm{Aa}$ & $124.9 \mathrm{Ba}$ & 130.6 & $132 \mathrm{~d}$ \\
\hline Cascata 967 & 488 & $132.9 \mathrm{Aa}$ & $135.0 \mathrm{Aa}$ & $130.3 \mathrm{Aa}$ & 132.7 & \\
\hline Cascata 1065 & 596 & $142.0 \mathrm{Aa}$ & $137.5 \mathrm{Aa}$ & $118.5 \mathrm{Bb}$ & 132.7 & \\
\hline Mean & & 128.6 & 118.6 & 109.8 & 119.0 & \\
\hline $\mathrm{CV}(\%)$ & & 3.49 & 2.75 & 4.03 & & \\
\hline
\end{tabular}

${ }^{\mathrm{z}}$ Means followed by the same upper case (rows) or lower case (columns) letters do not differ significantly (Skott-Knott test, $P \leq 0.05$ ).

y The group was formed based in Mahalanobis distance at $15 \%$.
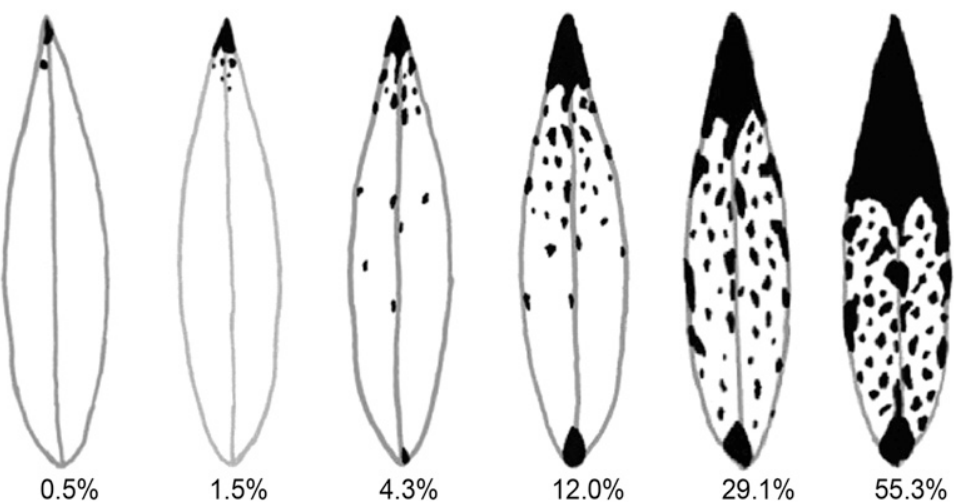

Fig. 2. Diagrammatic representation of the bacterial leaf spot (BLS) severity scale developed Citadin et al. (2008). Values are percent of leaf area with symptoms.

in $\mathrm{R}$ computer software ( $\mathrm{R}$ Development Core Team, 2010).

For clustering, HAD data were subjected to multivariate analysis using standardized Mahalanobis $\left(\mathrm{D}^{2}\right)$ dissimilarity distances. Clusters were identified using the unweighted pair group method with arithmetic mean (UPGMA), which was calculated using the GENES program (Cruz, 2006). The greatest distance (obtained by $\mathrm{D}^{2}$ ) was set at $100 \%$. The clusters were delimited based on a genetic distance of $15 \%$.

\section{Results and Discussion}

The average monthly temperature during this work ranged from 19.1 to $23.1^{\circ} \mathrm{C}$, which was considered to be within the ideal range for the development of BLS (Topp et al., 1993). The total precipitation during the studied period was $675 \mathrm{~mm}$ in 2008-09; $712 \mathrm{~mm}$ in 2009-10; and $1307 \mathrm{~mm}$ in 2010-11. These values represent the total precipitation recorded for 68,64 , and 80 rainy days, respectively.

The methodology used in this study resulted in a maximum HAD of $150 \mathrm{~d}$ (five
Table 2. Analysis of variance of the modified healthy leaf area duration (HAD) for 15 peach genotypes during three growing seasons, from 2008 to 2011.

\begin{tabular}{lrc}
\hline Source of variation & df & MS \\
\hline Genotype & 14 & $1441.75^{* *}$ \\
Growing season $(\mathrm{GS})$ & 2 & $3984.17^{* *}$ \\
Genotype $\times$ GS & 28 & $116.93^{* *}$ \\
Error & 90 & 16.81 \\
\hline
\end{tabular}

**Significant at $P \leq 0.01$.

$\mathrm{MS}=$ mean square

rates of defoliation and the incidence and severity of bacterial infection.

In the evaluation of adaptability and stability (Fig. 3), the first principal component (PC1) accounted for $87.7 \%$ of the variability in the data, and the second (PC2) accounted for $9.2 \%$. Therefore, the first two axes accounted for $96.9 \%$ of the spread in the data and could be considered to be a significant part of the interaction (i.e., above the threshold value of $80 \%$ ) (Gauch, 1988). In the GGE biplot model, the effects of genotype and genotype-environment interaction are multiplicative. The PC1 was directly connected to the genotypic effect allowing almost perfect correlation between the analyzed variable and $\mathrm{PC} 1$ score. Therefore, the $\mathrm{PC} 1$ represented $87.7 \%$ of the original HAD data in the experiment. The difference $(12.3 \%)$ is related to interaction genotypes $\times$ growing seasons (PC $2 \%$ to $9.2 \%$ ) and error (3.1\%); therefore, the PC1 score can replace HAD in the correlations with leaf characters.

The 2008-09 and 2009-10 growing seasons, in which the precipitation levels were $675 \mathrm{~mm}$ and $712 \mathrm{~mm}$, respectively, had similar variabilities and mean values. The genotype with highest HAD in these two cycles was 'Cascata 1065' (Fig. 3), which did not differ in both years from 'Cascata 967' and 'Conserva 985' (Table 1). The highest rainfall occurred during the 2010-2011 growing season with a total of $1307 \mathrm{~mm}$ recorded from the second half of September until the first half of March. In this growing season, the greatest HAD values were identified in 'Cascata 967' and 'Cascata 1065' (Fig. 3).

During the three growing seasons, the greatest mean HAD values were found in 'Cascata 1065', 'Cascata 967', 'Cascata 1055', and 'Conserva 985'. 'Cascata 1065' and 'Cascata 1055 ' were the most adapted among them, according to the GGE Biplot method (Yan and Kang, 2003). According to the same methodology, the greater stability was observed in 'Santa Áurea'. Moreover, the lower mean HAD values were observed in 'Conserva 1216', 'Conserva 1396', 'Conserva 1153', 'Libra', and 'Conserva 1127' (Fig. 3).

The genotypes 'Conserva 985' and 'Cascata 1065 ' were previously identified (Medeiros et al., 2011) as BLS-resistant using area under disease progress curves, whereas 'Conserva 1125 ' or 'Libra' and 'Conserva 1396' were considered susceptible.

We were able to separate the genotypes into three groups (Table 1) using UPGMA 


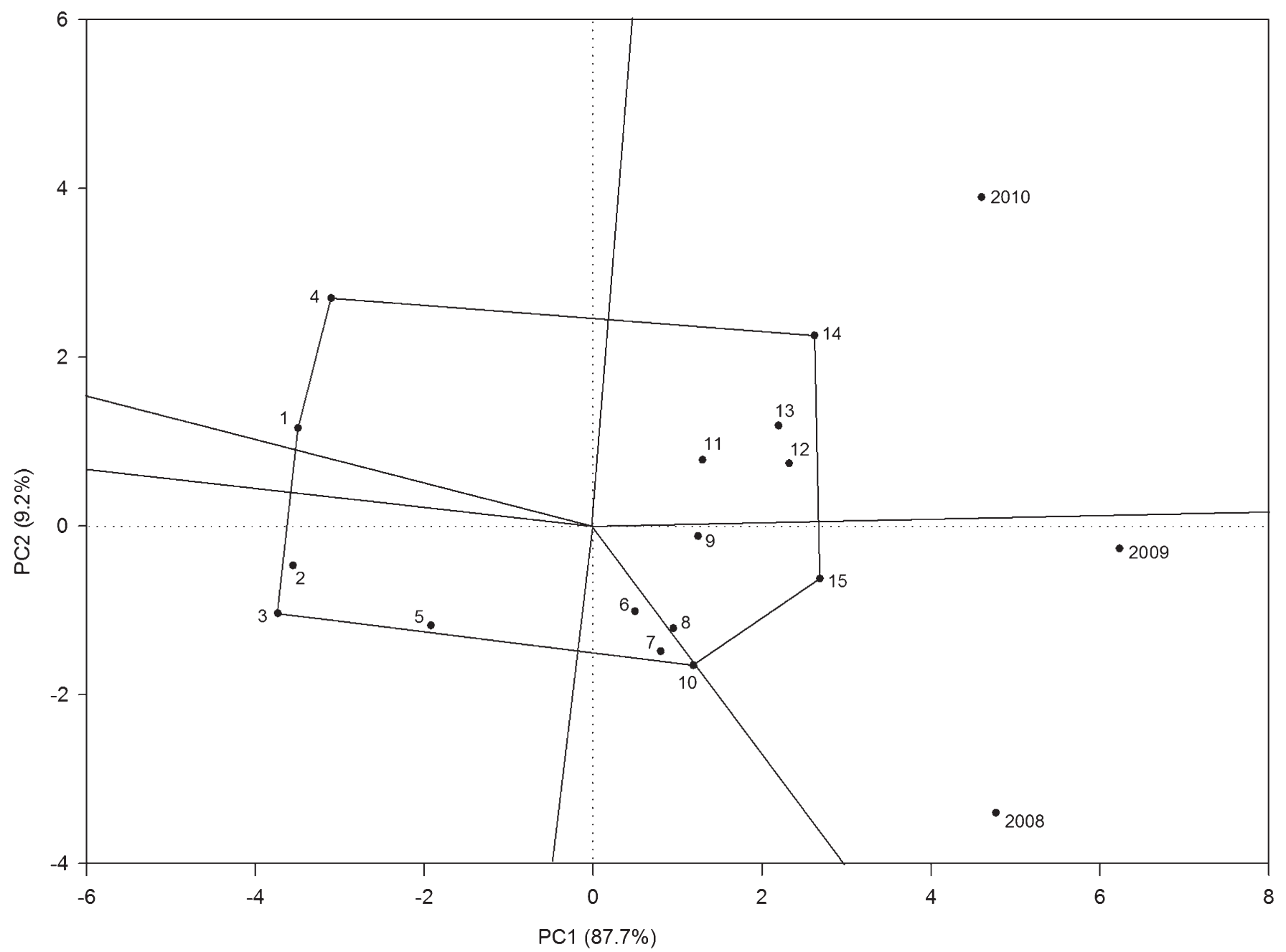

Fig. 3. Graphic representation of SREG analysis (GGE biplot) of 15 peach genotypes evaluated during three growth cycles (2008 to 2011 ) for HAD (healthy leaf area duration). 'Conserva 1216' (1), 'Conserva 1396' (2), 'Conserva 1153' (3), 'Libra' (4), 'Conserva 1127' (5), 'Conserva 681' (6), 'Conserva 871' (7), 'Cascata 587' (8), 'Santa Áurea' (9), 'Conserva 1186' (10), 'Cascata 1303' (11), 'Cascata 1055' (12), 'Conserva 985' (13), 'Cascata 967' (14), and 'Cascata 1065 ' (15).

analysis. The susceptible group consisted of genotypes that demonstrated susceptibility in all three growing seasons with a HAD of $\approx 102$ d: 'Conserva 1216', 'Conserva 1396', 'Conserva 1153', 'Libra', and 'Conserva 1127'. The moderately resistant group, with a mean HAD of $124 \mathrm{~d}$, included 'Conserva 681', 'Conserva 871', 'Cascata 587', 'Santa Aurea', 'Conserva 1186', and 'Cascata 1303'. The resistant group, with a mean HAD of $132 \mathrm{~d}$, included 'Cascata 1055', 'Conserva 985', 'Cascata 967', and 'Cascata 1065'. These resistant genotypes (with a mean HAD of 132 out of $150 \mathrm{~d}$ ) should be used as parents in breeding programs for BLS resistance.

There was little difference in HLAI pattern between the moderately resistant and resistant genotypes in the first two growing seasons. However, HLAI did decrease in the 2010-11 growing season, when there was an increase in the total precipitation and more rainy days (Fig. 4). Susceptible genotypes showed the same pattern in all three growing seasons. This consistent pattern suggests that there may be a genetic factor associated with leaf senescence and/or sensitivity to ethylene, like that observed by Ciardi et al. (2000) and Lund et al. (1998) in tomato or there may be a progressive decrease in the resistance of the leaves regardless of whether the environment is favorable to the spread of the disease.

Starting in January, there was an intense production of new shoots and leaves (sprouting) in the genotypes 'Libra' and 'Conserva 1127 ' originating from the apical stem. This new growth generated shoots $\approx 15 \mathrm{~cm}$ long with one flower bud per node and a vegetative apex. This new foliage remained until natural senescence (mid-May) with little BLS damage. This behavior could compensate, in part, for the loss of spring foliage.

The correlation between PC1 and the leaf features (Table 3$)$ was significant $(P \leq 0.05)$ and negatively correlated to dry matter ( $\mathrm{g} / \mathrm{leaf}$ ), leaf blade length, leaf length (with or without petiole), and leaf area $\left(\mathrm{cm}^{2} / \mathrm{leaf}\right)$. Despite the small number of genotypes, these results suggest that genotypes with larger leaves have less resistance to BLS, and none of the other variables were significant as indirect predictors of the reaction of a genotype to BLS.
The disease progression differed between susceptible and resistant genotypes (Table 4). Days considered to be dry/mild and dry/hot had no correlation with disease progression (HLAI). The susceptible genotypes were strongly influenced by humid days regardless of the daily mean temperature, whereas disease progression in the resistant genotypes was only influenced by humid/hot days. According to Zehr and Shepard (1996), RH, leaf wetness, the occurrence of rain and/or other factors that cause water congestion are directly linked to the development of BLS; however, once disease is established, the rate of lesion development increases with temperature.

The mechanisms involved in resistance to BLS can be mechanical or biochemical. On humid/hot days, with coalescence of the lesions, mechanical barriers are limited and biochemical mechanisms are diluted (Zehr and Shepard, 1996). The correlation with higher BLS susceptibility with larger leaves (Table 3) may suggest larger leaves remain wet longer or more prone to mechanical damage.

The onset of budburst is said to occur when $5 \%$ of the vegetative buds are at the 

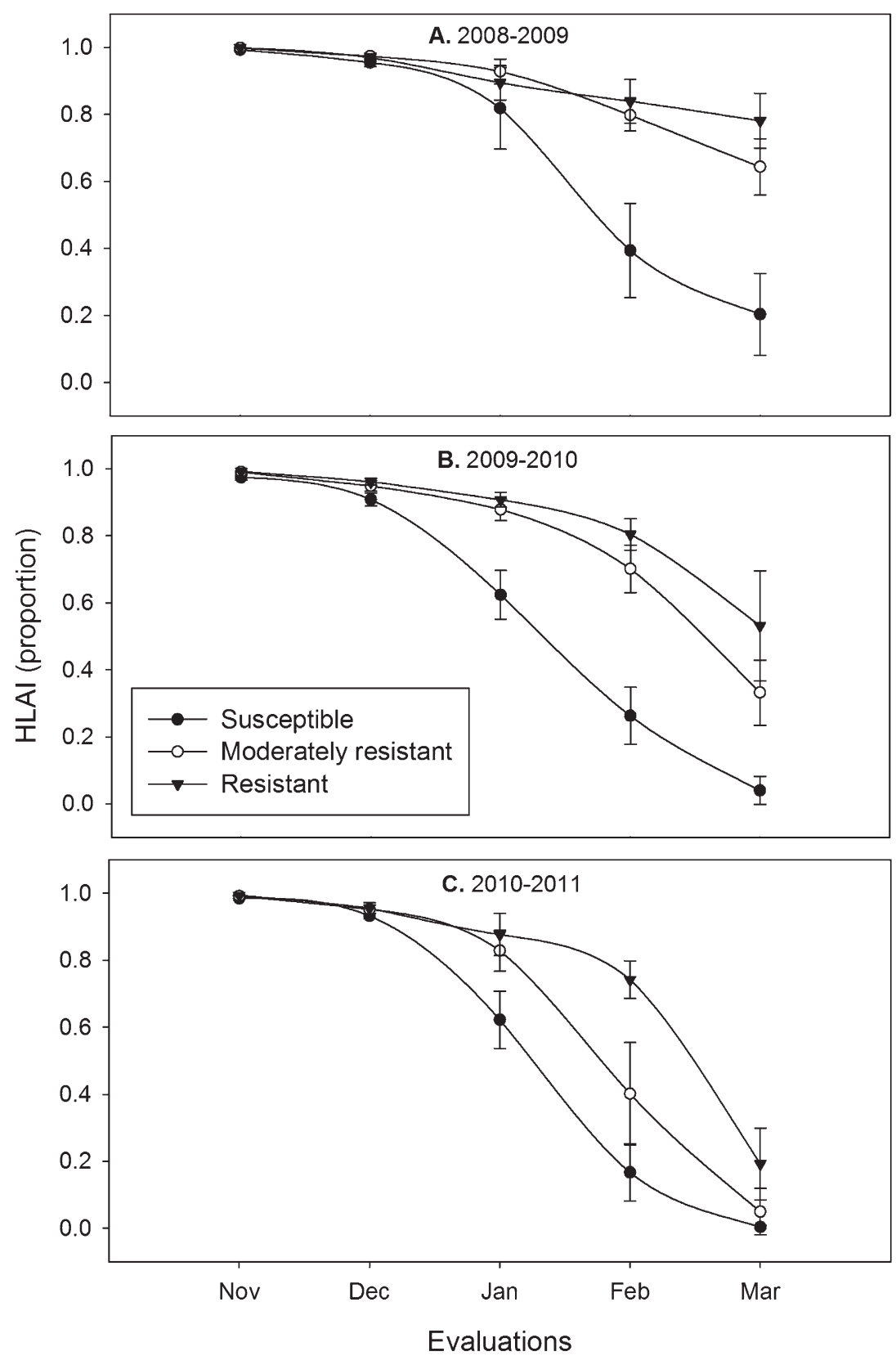

Fig. 4. Graphic representation of healthy leaf area index (HLAI) to three groups of peach genotypes during three growing seasons: (A) 2008-09, (B) 2009-10, and (C) 2010-11.

Table 3. Correlations between leaf features and bacterial leaf spot resistance estimated by the first principal component (PC1) of SREG analysis (GGE biplot).

\begin{tabular}{lc}
\hline Leaf characters & PC1 \\
\hline Dry material $(\mathrm{g} /$ leaf $)$ & $-0.59^{*}$ \\
Length of leaf blade $(\mathrm{cm})$ & $-0.57^{*}$ \\
Leaf length with petiole $(\mathrm{cm})$ & $-0.56^{*}$ \\
Leaf area $\left(\mathrm{cm}^{2} /\right.$ leaf $)$ & $-0.56^{*}$ \\
Fresh material $(\mathrm{g} / \mathrm{leaf})$ & -0.51 \\
Width of leaf blade $(\mathrm{cm})$ & -0.4 \\
Dry matter content $(\%)$ & -0.4 \\
Petiole length $(\mathrm{cm})$ & -0.24 \\
Leaf format $(\mathrm{length} /$ width) & -0.13 \\
Dry material $\left(\mathrm{g} \cdot \mathrm{cm}^{-2}\right)$ & 0.03 \\
Fresh material $\left(\mathrm{g} \cdot \mathrm{cm}^{-2}\right)$ & 0.34 \\
Number of stomata & 0.41 \\
\hline
\end{tabular}

*Significant at $P \leq 0.05$, probability of error calculated by a $t$ test.
The reciprocity between date of budburst and yearly HAD in the same growing seasons is evidenced by the significant correlation between start of budburst in 2008/ HAD2008 and start of budburst in 2009/ HAD2009 (Table 5). That is, early budburst, at least partially, contributed to the increased intensity of the disease as a result of the earlier exposure of leaves to the bacteria.

The floral buds were even more sensitive to shallow dormancy than were vegetative buds, primarily as a result of the relatively low amount of cold required to break dormancy. We identified a significant positive correlation between flowering dates and HAD from the previous year: the longer the duration of healthy leaf area, the later the occurrence of blooming in the next cycle. The same was observed for budburst (Table 5).

The ripening date was significantly related to the respective HAD. Early ripening requires higher rates of dry matter accumulation in fruits and more rapid translocation of essential leaf elements, which increases the susceptibility to foliar diseases. In addition, ripening is marked by the release of ethylene, which acts as a senescence hormone, inducing increased disease susceptibility in leaves typical of the late season in most crops. Ethylene production in lesions caused by BLS can induce chlorosis and necrosis of healthy tissues adjacent to the lesion, especially in ethylene-sensitive genotypes (Ciardi et al., 2000; Lund et al., 1998; Stall and Hall, 1984). In resistant genotypes, chlorosis is rarely observed as a result of the isolation of lesions by a hypersensitivity reaction in the leaves. On the resistant genotypes, small punctiform or small lesions, with reduced or no chlorotic spots, were observed on the leaf area with a shot hole in the center of the lesion, indicating a probable hypersensitive reaction. This reaction is mainly determined by the metabolic capacity of the plant and could lead to a high degree of disease resistance.

Although BLS is recognized as one of the most important diseases affecting commercial peach cultivation, we found no significant relationship between yield and leaf disease severity (Table 5). Only highly productive genotypes were selected for our study. Thus, even if the peach selection was susceptible to BLS, productivity loss would be minimal. The relationship between production and HAD was not significant, within or between years, indicating that there were compensatory mechanisms acting to minimize the premature loss of foliage (regrowth in the fall and earlier budburst in the austral winter).

In summary, none of the tested genotypes were immune to BLS. The most resistant genotypes were 'Conserva 985', 'Cascata 967', 'Cascata 1065', and 'Cascata 1055'. There was a reduction in the average duration of healthy leaf area that correlated with increased precipitation during the vegetative cycle. The dry matter (g/leaf), leaf blade length, leaf length (with petiole) and leaf area $\left(\mathrm{cm}^{2} / \mathrm{leaf}\right)$ were inversely correlated with the genotype 
Table 4. Correlations between healthy leaf area index (HLAI) and number of days grouped into four classes of daily mean relative humidity $(\mathrm{RH}) \times$ daily mean temperature $(\mathrm{DMT})$ on the date of assessment during the three evaluated growing seasons (2008 to 2011), based on 15 observations.

\begin{tabular}{lccr}
\hline Classification & Susceptible & Moderately resistant & Resistant \\
\hline Dry/mild & $-0.15 \mathrm{NS}$ & $-0.34 \mathrm{NS}$ & $-0.30 \mathrm{NS}$ \\
Dry $_{\mathrm{hot}^{\mathrm{y}}}$ & $-0.30 \mathrm{NS}$ & $-0.13 \mathrm{NS}$ & $-0.15 \mathrm{NS}$ \\
Humid/mild & $-0.70^{* *}$ & $-0.49 \mathrm{NS}$ & $-0.47 \mathrm{NS}$ \\
Humid $/$ hot $^{\mathrm{w}}$ & $-0.96^{* *}$ & $-0.85^{* *}$ & $-0.80^{* *}$ \\
\hline
\end{tabular}

${ }^{\mathrm{z}} \mathrm{RH} 70 \%$ or less and DMT $20^{\circ} \mathrm{C}$ or less

${ }^{\mathrm{y}} \mathrm{RH} 70 \%$ or less and DMT greater than $20{ }^{\circ} \mathrm{C}$.

${ }^{\mathrm{x}} \mathrm{RH}$ greater than $70 \%$ and DMT $20{ }^{\circ} \mathrm{C}$ or less.

${ }^{\text {w }} \mathrm{RH}$ greater than $70 \%$ and DMT greater than $20^{\circ} \mathrm{C}$

Ns, **Nonsignificant or significant at $P \leq 0.01$, probability of error calculated by a $t$ test.

Table 5. Correlation coefficients between phenologic characteristics (budburst, flowering, and maturation) and peach production with healthy leaf area duration (HAD) during three growing seasons from 2008 to 2011 based on 15 observations.

\begin{tabular}{|c|c|c|c|}
\hline Variables & HAD2008 & HAD2009 & HAD2010 \\
\hline Start of budburst in 2008 & $0.82^{* *}$ & - & - \\
\hline Start of budburst in 2009 & $0.62 *$ & $0.57 *$ & - \\
\hline Start of budburst in 2010 & - & $0.64 * *$ & $0.48 \mathrm{NS}$ \\
\hline Start of flowering in 2008 & - & - & - \\
\hline Start of flowering in 2009 & $0.58 *$ & - & - \\
\hline Start of flowering in 2010 & - & $0.63 *$ & - \\
\hline Date of full maturity in 2008 & $0.61 *$ & - & - \\
\hline Date of full maturity in 2009 & - & $0.52 *$ & - \\
\hline Date of full maturity in 2010 & - & - & $0.58 *$ \\
\hline Yield in 2008 & $0.24 \mathrm{NS}$ & $0.16 \mathrm{NS}$ & $0.15 \mathrm{NS}$ \\
\hline Yield in 2009 & $0.49 \mathrm{NS}$ & $0.38 \mathrm{NS}$ & $0.36 \mathrm{NS}$ \\
\hline Yield in 2010 & $0.44 \mathrm{NS}$ & $0.36 \mathrm{NS}$ & $0.26 \mathrm{NS}$ \\
\hline
\end{tabular}

Ns, ${ }^{*}, * *$ Nonsignificant, significant at $P \leq 0.05$ or $P \leq 0.01$, respectively; probability of error calculated by a $t$ test.

resistance to BLS. The HAD of susceptible genotypes was influenced by wet days regardless of the temperature. Most susceptible genotypes were those with earlier budburst and early ripening fruit. There was no relationship between HAD and productivity.

\section{Literature Cited}

Battilani, P., V. Rossi, and A. Saccardi. 1999. Development of Xanthomonas arboricola pv. pruni epidemics on peaches. J. Plant Pathol. 81:161-171.

Bhering, S.B., H.G. dos Santos, L.A. Bognola, G.R. Cúrcio, C.V. Manzatto, W. de Carvalho, Jr., C.D.S. Chagas, M.L.D. Aglio, and J.S. de Souza. 2008. Mapa de solos do Estado do Paraná: Legenda atualizada. EMBRAPA/IAPAR, Rio de Janeiro, Brazil.

Ciardi, J.A., D.M. Tieman, S.T. Lund, J.B. Jones, R.E. Stall, and H.J. Klee. 2000. Response to
IBRAF-Instituto Brasileiro de Frutas. 2012. Estatísticas: Importação e exportação de frutas. 3 Jan. 2012. <http://www.ibraf.org.br/>.

Keil, H.L. and H.W. Fogle. 1974. Orchard susceptibility of stone apricot, peach and plum cultivars and selections to Xanthomonas pruni. Fruit Var. Jour. 28:16-19.

Kretzschmar, A.A., E.A. Rosseto, and O.M. Martins. 1998. Resistência de algumas cultivares de pessegueiro a Xanthomonas campestris pv. pruni inoculadas por infiltração em folhas destacadas. Rev. Bras. Frut. 20:213-219.

Lloyd, J. and D. Firth. 1990. Effect of defoliation time on depth of dormancy and bloom time for low-chill peaches. HortScience 25:1575-1578.

Lund, S.T., R.E. Stall, and H.J. Klee. 1998. Ethylene regulates the susceptible response to pathogen infection in tomato. Plant Cell 10: 371-382.

Martins, O.M. and M.C.B. Raseira. 1996. Sources of bacterial spot resistance in plum cultivars. Fruits Var. J. 50:156-159.

Medeiros, J.G.S., I. Citadin, I. dos Santos, and A.P. Assmann. 2011. Reaction of peach tree genotypes to bacterial leaf spot caused by Xanthomonas arboricola pv. pruni. Scientia Agr. 68: $57-61$.

R Development Core Team. 2010. R: A language and environment for statistical computing. $\mathrm{R}$ Foundation for Statistical Computing, Vienna, Austria.

Scariotto, S. 2011. Fenologia e componentes de rendimento de pessegueiro em condições subtropicais. MSc diss., Univ. Tec. Fed. Paraná, Pato Branco. 3 Jan. 2012. <http://www.pb.utfpr. edu.br/bibliotecadigital/>.

Stall, R.E. and C.B. Hall. 1984. Chlorosis and ethylene production in pepper leaves infected by Xanthomonas campestris pv. vesicatoria. Phytopathology 74:373-375.

Xathomomnas campestris pv. vesicatoria in tomato involves regulation of ethylene receptor gene expression. Plant Physiol. 123:81-92.

Citadin, I., A.P. Assmann, S.M. Mazaro, A. Gouvêa, M.A. Danner, and G. Malagi. 2008. Escala diagramática para avaliação da severidade de bacteriose em pessegueiro. Rev. Bras. Frut. 30:327-330.

Cruz, C.D. 2006. Programa genes: Biometria. Editora UFV, Viçosa, MG.

FAOSTAT - Statistical Database of the Food and Agriculture Organization of the United Nations. 2012. Production crops to 2010: Peaches and nectarines. 3 Jan. 2012. <http://faostat.fao. org/>.

Gauch, H.G., Jr. 1988. Model selection and validation for yield trials with interaction. Biometrics 44:705-715.

Horsfall, J.C. and R.W. Barrat. 1945. An improved grading system for measuring plant diseases. Phytopathology 35:665.
Topp, B.L., W.B. Sherman, R.E. Stall, G.V Minsavage, and C.J. Wilcox. 1993. Comparison of greenhouse methods for assessing resistance to bacterial leaf spot in plum. J. Amer. Soc. Hort. Sci. 118:667-671. tion, disease and growth. Phytopathology 77: 393-398.

Werner, D.J., D.F. Ritchie, D.W. Cain, and E.L. Zehr. 1986. Susceptibility of peaches and nectarines, plant introductions, and other Prunus species to bacterial spot. HortScience 21:127-130.

Yan, W. and M.S. Kang. 2003. GGE Biplot analysis: A graphical tool for breeders, geneticists, and agronomists. CRC Press, Boca Raton, FL.

Zehr, E.I. and D.P. Shepard. 1996. Bacterial spot of peach as influenced by water congestion, leaf wetness duration, and temperature. Plant Dis. 80:339-341.
Waggoner, P.E. and R.D. Berger. 1987. Defolia- 